症例

総胆管切開切石術後に発症した右肝動脈・肝内胆管瘻による 胆道出血の 1 例

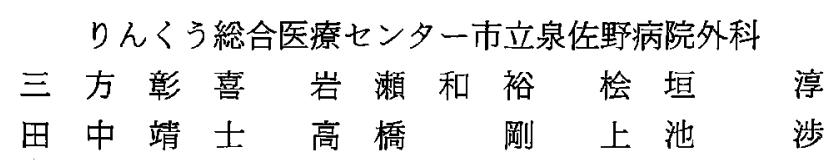

症例は71歳, 女性. 総胆管結石症の再発に対して総胆管切開切石術, 十二指腸乳頭括 約筋形成術を施行した。術後 Tチューブからの出血なく, 術後17日目, Tチューブを抜 去した. 術後20日目, 血液検查にて貧血を認め, 上部消化管内視鏡検查を施行したが, 胃十二指腸に嫕䁑は認めず，十二指腸乳頭括約筋形成部からの出血も認めなかった。術 後27日目, 大量吐血にてショック状態となり，呼吸停止をきたした。茫蘇生後，緊急 大動脈カテーテル検查を施行したところ, 右肝動脈前下区域枝から総胆管への造影剤の 漏出を認め,コイルおよびスポンゼルを用いて右肝動脈前下区域枝の塞栓を施行した。 塞栓術後, 血行動態は安定し, 肝機能の低下や, 肝膿湟を併発することなく軽快退院し た.

索引用語：胆道出血, 総胆管切開切石術, TAE (transarterial embolization)

はじめに

胆道出血は肝動脈溜, 胆堧動脈溜破裂や肝外傷を契 機として発症することが多いとされてきたが, 近年, PTCD 後などの医源性の報告が増加している.今回わ れわれは, 総胆管結石症の再発に対して総胆管切開切 石術, 経十二指腸乳頭括約筋形成術を施行後, 大量吐 血にてショック状態に陥り, 救命しえた胆道出血の 1 例を経験したので報告する。

\section{症例}

症例: 71歳, 女性.

主訴: 発熱.

既往歴：68歳時, 総胆管結石にて総胆管切開切石術.

家族歴：特記すべきことなし。

現病歴: 平成11年 9 月頃より $37^{\circ} \mathrm{C}$ 台の発熱を認め, 当院内科を受診した．血液検查にて肝トランスアミナ 一ゼ, 胆道系醉素の上昇を認め, MRCP 扝上びCT 検 查にて再発総胆管結石症と診断され，手術目的にて平 成11年10月13日当科入院した。

入院時現症：体格中等。栄養状態良好。眼球結膜に

2002年 7 月 26 日受付 2002 年 9 月19日採用

〈所属施設住所〉

テ598-8577 泉佐野市りんくう往来北 $2-23$
軽度の黄染を認めた。腹部は平坦軟で圧痛なく，腫瘤 も触知しなかった。

入院時検查所見: 末梢血液検查で白血球数が $11,500 / \mathrm{mm}^{3}$, 生化学検査で CRP $0.8 \mathrm{mg} / \mathrm{dl}$, GOT 176 IU/L, GPT 117IU/L, T. Bil $2.1 \mathrm{mg} / \mathrm{dl}, \gamma-\mathrm{GTP} 236$ IU/L, ALP 382IU/L を示した以外異常值は認めなか った.

腹部 CT 検査：肝内胆管の著明な拡張と胆管内気腫 を認め, 下部胆管に結石を認めた（図 1 )。

MRCP 検査：肝内胆管, 総胆管の著しい拡張と下部 胆管に結石による類円形の陰影欠損を認めた (図 2). 以上の所見から総胆管結石の再発と診断し，同年10 月22日手術を施行した。

手術所見 : 上腹部経腹直筋切開にて開腹, 総胆管は $18 \mathrm{~mm}$ に拡張し, 軽度の壁肥厚を認めた。十二指腸上 部で総胆管を切開したところ, 胆管内に多数のビリル ビン結石と胆泥を認め，切石鉗子を用いて切石した。 再発結石であることから経十二指腸乳頭括約筋形成術 を付加し，また，術中胆道鏡検查にて遗残結石や胆管 内腔に異常所見は認めなかったが，微細な胆泥を認め たため Tチューブを留置し手術を終了した。

術後経過：術後経過良好で, 術後第14病日に T ューブ造影を行い, 遺残結石のないことを確認し, 術 

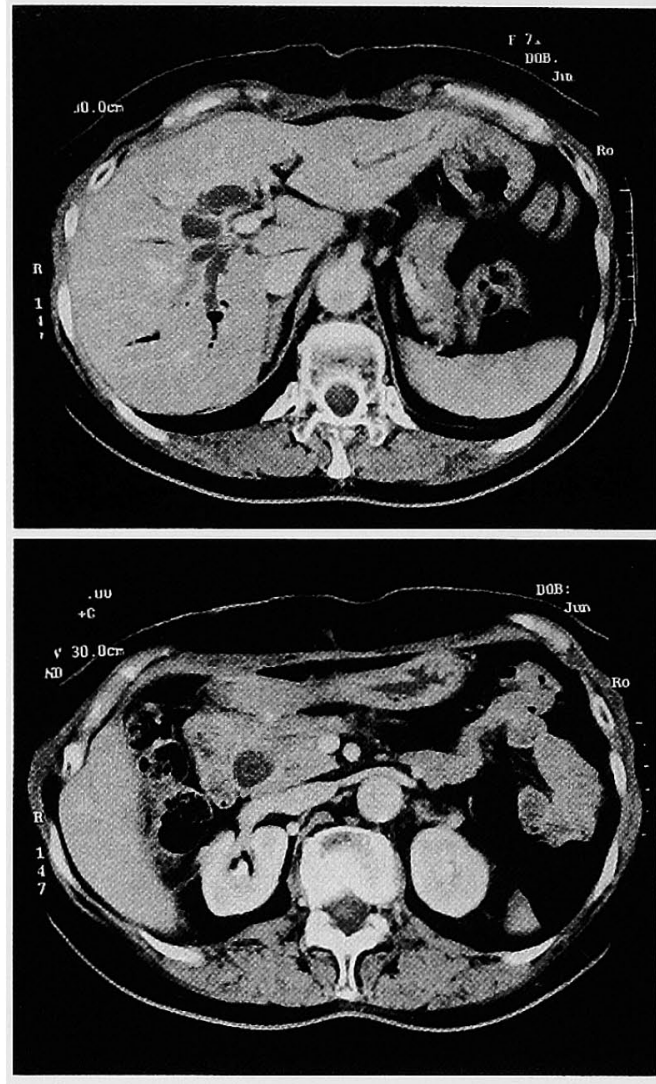

図 1 腹部 CT：肝内胆管の著明な拡張と胆管内気 腫を認め，下部胆管には結石を認めた。

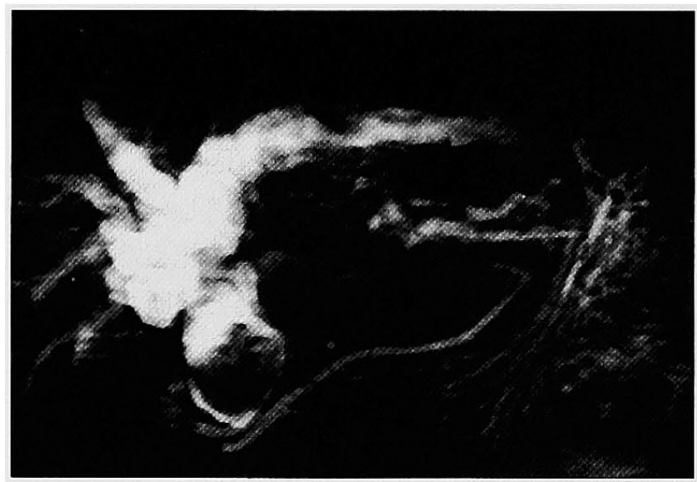

図 2 MRCP：肝内胆管, 総胆管の著明な拡張と,下部 胆管に結石による類円形の欠損を認めた。

後第17病日 Tチューブを抜去したが，チューブからの 出血は経過をと扎て認めなかった，術後第20病日の 血液検查で貧血を認めたため上部消化管内視鏡検查を 施行したが霄十二指腸に謴演は認めず，十二指腸乳頭
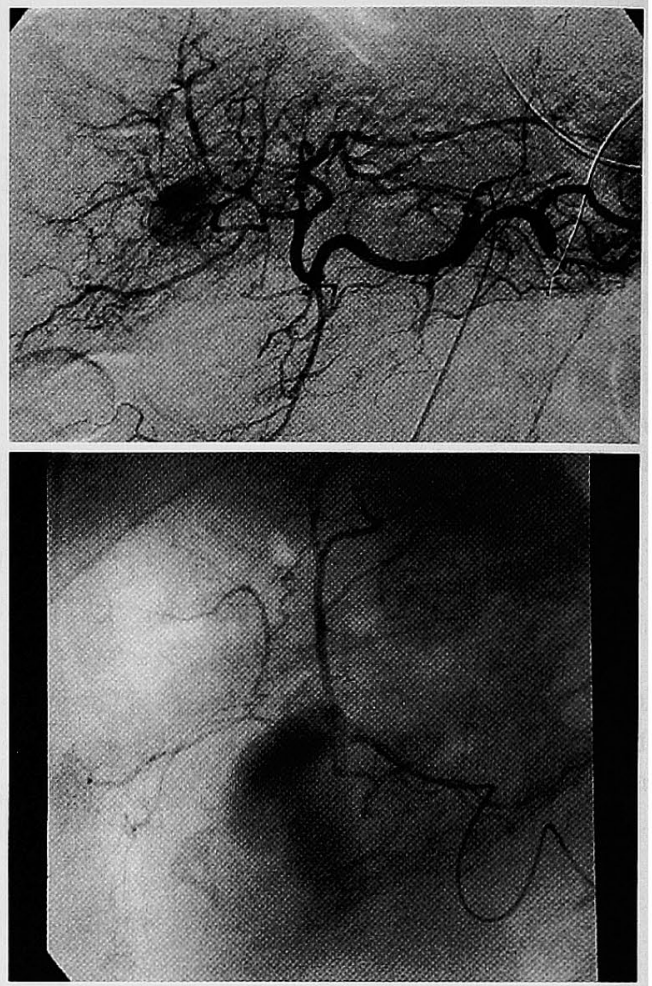

図 3 血管造影：A）腹腔動脈造影で肝動脈右枝か ら造影剂の血管外漏出を認めた。Ｂ）選択的右肝動 脈造影で右肝動脈前下区域枝から造影剤の血管外 漏出在認め, 総胆管が造影された。

$\frac{\mathrm{A}}{\mathrm{B}}$

括約筋形成部からの出血も認めなかった，以後，貧血 の増悪を認めなかったが, 術後第27病日, $1,000 \mathrm{ml}$ の大 量吐血をきたし，ショック状態となり呼吸停止をきた した. 気管内捙管後, 急速輸血を行いつつ, 緊急動脈 造影検查を施行した。

動脈造影検査：上部消化管からの出血を疑い，腹腔 動脈造影を行った。在肝動脈から造影剂の血管外漏出 を認めたため，選択的右肝動脈造影を行ったところ， 右肝動脈前下区域枝から造影剂が大量に血管外に漏出 し，総胆管が描出された(図 3 )、コイル，スポンゼル を用いて破綻した右肝動脈前下区域枝の末梢側を塞栓 した後ここの中枢側を塞栓し止血した（図 4).

$\mathrm{TAE}$ 後, 循環動態は改善し, 肝機能の低下や, 肝膿 瘍を形成することなく，12月10日退院した。塞栓術後 2 年 6 力月経過した現在, 総胆管結石の再発, 再出血 はみられず全身状態は良好である。 


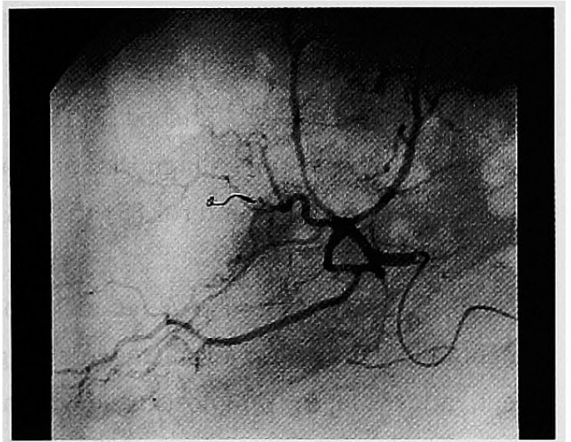

図 4 TAE 後の血管造影：総肝動脈からの 造影では造影剤の血管外漏出は認めず，塞 栓術にて止血しえた。

\section{考 察}

Hemobilia (胆道出血) は何らかの原因で胆道と血管 が交通を生じ，血液が十二指腸乳頭部に到達した状態 と定義され, 1948年 Sandblom ${ }^{11} に よ り$ 命名された疾患 である。

発生原因は外傷性と非外傷性に分類され，前者とし て肝外傷やPTCD など医療行為に起因するものが, 後 者として肝胆道系の炎症, 感染, 腫湯に起因するもの があげられる.1972年の Sandblom の報告では，外傷 や炎症に起因するものが多いとされているが2), 近年, 旰生検や，PTCD，総胆管への stent 留置など interventional radiology の導入とともに，医源性胆道出血 の割合が著增し ${ }^{34)}$ ，谷村ら5)の報告では約半数を占め るようになった。自験例は血管造影検查で肝動脈瘤は 認めず， Tチュープ留置部と動脈胆管瘦形成部とは離 れていた，総胆管結石切石術時の操作による胆管壁損 傷の場合は大量出血に至ることは少ないとされ゙，自 験例でも丁チューブからの出血は経過を通して認め なかったことから，繰り返した胆管炎，再発結石によ り拡張・脆弱化した胆管内に十二指腸乳頭括約筋形成 術により胆汁, 膵液の混合液が逆流し, 胆管壁の損傷 をきたし動脈胆管瘦を形成したものと思われる。内視 鏡的十二指腸乳頭括約筋切開術後の出血は重篤な合併 症の一つであるが7), 総胆管切開切石術, 経十二指腸乳 頭括約筋形成術後の炎症による肝動脈胆管瘦による大 量胆道出血の報告例は，われわれが検索しえた限り認 めなかった ${ }^{8)}$. 上部胆管に狭窄のない再発総胆管結石 症例に対しては，胆管空腸吻合術や胆管十二指腸吻合 汸など胆管消化管吻合術が施行されることも多く，胆 管の拡張が著明な自験例でも考慮すべきであったと思
われる。

胆道出血の主要症状はタール便 $89 \%$, 胆道疝痛 $68 \%$, 吐血 $60 \%$ ，黄疸 $60 \%$ ，と報告されて扣り ，胆道内凝血 塊の形成と消化管への凝血塊排出による胆道内圧の変 化により，これらの症状が間欠的に繰り返されるのが 特徴である。自験例では十二指腸乳頭括約筋形成術後 であり，胆管内に流出した血液は凝血塊を形成するこ となく消化管へ流出するため，胆道内圧の上昇をきた さず，胆道疝痛などの症状は認めず大量吐血にて発症 したものと思われた。

診断は上部消化管内視鏡検查にて十二指腸乳頭部か らの出血を確認することにあるが，前述したように間 欠的出血が特徴であることから $30 \%$ が確認されるのみ であり ${ }^{10)}, \mathrm{CT}, \mathrm{MRI}$ 検査, 赤血球シンチグラフィー, 血管造影検査の併用が有用とされている．自験例では 内視鏡検查による十二指腸乳頭部の出血や CT 検査に よる胆管内血腫は診断不能であり，吐血によるショッ ク状態後, 血管造影検査を施行し, 診断可能となった。 胆道出血の治療は，動脈性出血加静脈性（門脈性） 出血かで治療法が変わってくる. 静脈性出血の多くは 保存的治療により止血可能であるとされ, Ito ら ${ }^{11}$ が報 告した内視鏡下逆行性硬化療法などの処置を要するも のは稀であった。一方，動脈性出血に対しては，肝切 除術や肝動脈結禁術が行われてきたが, 1976年 Walter ら ${ }^{12} の$ 血管造影による診断と TAEについての報告以 来, TAE が第一選択の治療法となり, 岡崎ら ${ }^{13)}$ は胆道 出血に対する緊急 TAE22例全例で止血に成功してい る.自験例ではカテーテルを右肝動脈前下区域枝まで 超選択的に指入可能であったため，胆管動脈瘦の近位 側と遠位側を塞栓し，その血流を完全に遮断すること により止血しえた．肝膿瘍や肝不全などの合併症も危 惧されるが，緊急時には診断と治療を同時かつ迅速に 施行できる有効な手法であると思われた。

\section{結語}

総胆管結石症の再発症例に対して総胆管切開切石 術, 経十二指腸乳頭部括約筋形成術を施行後, 大量吐 血にて発症した胆道出血の 1 例を経験した。診断と治 療に動脈造影検查が有用であった。

\section{文献}

1) Sandblom $P$ : Hemorrhage into biliary tract following trauma, traumatic hemobilia. Surgery $24: 571-580,1948$

2) Sandblon P : Haemobilia (biliary tract hemorrhage). History, Pathology, Diagnosis, Treat- 
ment. Ed by Thmas CC, Springfield, Illinois, 1972, p5-117

3) 興石 剛, 磯本一郎, 中村和邦他：TAE が著効し た医原性胆道出血の 1 例. 臨放線 $41: 817-820$, 1996

4）森田翼, 岡田浩, 伊藤哲史他：肝生検後の hemobiliaに対し, 経カテーテル的動脈塞栓術 (TAE)で止血しえた一例. 朋蔵 $39: 42-45$, 1998

5）谷村 弘，笠野泰生，野口浩平：胆道出血の診断 と治療。綜合臨 $43: 2450-2454,1994$

6) 山本正之：肝 - 胆道系症候群 その他の肝 - 胆道 系疾患を含めて 胆道出血 (hemobilia). 日臨 566-568, 1995.

7）金子栄蔵, 原田英雄, 春日井達造他：消化器内視 鏡の偶発症に関する第 2 回全国調查報告-1998年 より1992年までの 5 年間一. Gastroenterol En dosc $37: 642-653,1995$

8) Gabrielsen $K$, Sondenaa K, Halvorsen L : Massive haemobilia in a patient with residual stone after choledochoduodenostomy. Case report: treatment with endoscopic papillotomy. Acta Chir Scand 152 : 387-388, 1986

9) Bloechle C, Izbicki JR, Rashed MY, et al: Hemobilia : presentation, diagnosis, and management. Am J Gastroenterol 89 : 1537-1540, 1994

10) Curet $P$, Baumer $R$, Roche $A$, et al: Hepatic hemobilia of traumatic or iatrogenic origin: recent advances in diagnosis and therapy: review of the literature from 1976 to 1981. World J Surg $8: 2-8,1984$

11) Ito $T$, Segawa $T$, Kanematsu $T$ : Successful endoscopic injection sclerotherapy for bleeding from bile duct varices. Surg Today $27: 174-$ 176,1997

12) Walter JF, Paaso BT, Cannon WB: Successful transcatheter embolic control of massive hematobilia secondary to liver biopsy. Am J Roentogenol $127: 847-849,1976$

13）岡崎正敏，東原秀行：消化管出血に対する救急動 眽塞栓術。消外セミナー $70: 17-23,1998$

\title{
LIFE-THREATENING GASTROINTESTINAL BLEEDING AFTER CHOLEDOCHOLITHOTOMY DUE TO HEPATIC ARTERY PERFORATING INTO THE RIGHT HEPATIC DUCT
}

\author{
Shoki MIKATA, Kazuhiro IWASE, Jun HIGAKI \\ Yasushi TANAKA, Tsuyoshi TAKAHASHI and Wataru KAMIIKE \\ Department of Surgery, Rinku General Medical Center, Izumisano Municipal Hospital
}

A 71-year-old woman was performed a choledocholithotomy and a papilloplasty for recurred choledocholithiasis. We recognized no bleeding from a $T$-tube through a postoperative course, and the $\mathrm{T}$-tube was removed on the 17th day after the operation. Although a drop in hemoglobin was noted on the 20th day after the operation, there were no ulcer in the stomach, duodenum and no bleeding from the papilloplasty site. On the 27 th day after the operation, massive hematemesis occurred, and then the patient went into hemorrhagic shock and respiratory arrest. After resuscitation, an emergency celiac and selective hepatic arteriography was performed. It demonstrated leakage of a contrast media from the branch of the right hepatic artery into the common bile duct. TAE was carried out and the bleeding was controlled successfully. The patient was discharged from the hospital a few days later without elevation of serum value of liver enzymes and liver abscess. 